Revue Française de Civilisation Britannique

\title{
The NHS at the Heart of the Election Campaign.
}

Le système de santé britannique au coeur de la campagne

\section{Louise Dalingwater}

\section{OpenEdition}

\section{Journals}

Electronic version

URL: http://journals.openedition.org/rfcb/568

DOI: $10.4000 / \mathrm{rfcb} .568$

ISSN: 2429-4373

\section{Publisher}

CRECIB - Centre de recherche et d'études en civilisation britannique

\section{Electronic reference}

Louise Dalingwater, «The NHS at the Heart of the Election Campaign. », Revue Française de Civilisation Britannique [Online], XX-3 | 2015, Online since 01 December 2015, connection on 20 April 2019. URL : http://journals.openedition.org/rfcb/568; DOI : 10.4000/rfcb.568

This text was automatically generated on 20 April 2019.

Revue française de civilisation britannique est mis à disposition selon les termes de la licence Creative Commons Attribution - Pas d'Utilisation Commerciale - Pas de Modification 4.0 International. 


\title{
The NHS at the Heart of the Election Campaign.
}

\author{
Le système de santé britannique au coeur de la campagne
}

\author{
Louise Dalingwater
}

\section{Introduction}

One of the key subjects of debate in the run up to the 2015 general election in the UK was public services. Labour's election poster claimed "The Tories want to cut spending on public services back to the level of the 1930s, when there was no NHS." The National Health Service (NHS) is a huge organisation, with over one million staff. The configuration for current health services was set forth in 1948 under the National Health Service Act which ensured a comprehensive system of health for all citizens, entirely free at the point of use. This Act allowed for local authorities to provide welfare and health services. However, since this legislation was implemented, the social, demographic and technological framework of Britain has changed. In particular, life expectancy has increased dramatically. Increased longevity, the retirement of the baby generations of the 1940s and the expected weight of the retirement of the 1960s baby boomers has meant that more people are living longer, which in turn means greater health demands. In addition, there has been significant medical and technological progress, which has resulted in rising drug and medical device costs.

2 The NHS has been described as a monster too big to reform. This has not prevented successive governments from attempting a vast number of reforms: devolution, centralisation, purchaser-provider split, commissioners, and GP fund holders, all of which have had their downsides and received extensive criticism. The essential problem is that the organisation is very costly to deliver, but public opinion is strongly against the privatisation of health services.

3 Despite pledging not to make any top-down reorganisation of the NHS during the 2010 election campaign, the Lib-Con coalition has brought about sweeping changes to the 
National Health Service since then. Much focus has been on making the NHS function more efficiently. This paper will thus examine the issues that were debated during the 2015 election campaign relating to the NHS. It will also consider how the results of the elections might influence the future running of health services in the UK. The main focus will be on NHS England because health has been devolved to Scotland, Wales and Northern Ireland separately since the late 1990s and each of these countries takes a different approach to health services.

\section{The crisis of the NHS: key points of analysis}

The 2015 election saw the emergence of the health service and its future as one of the key points on the election battleground. The NHS hardly featured in the manifestos of the 2010 general election. Indeed, Labour, which usually promotes its good record on prioritising the NHS, failed to take any particular standpoint in 2010. The Conservatives had made this more difficult by stating it would outspend Labour and that this was one of the areas that would be excluded from cuts. However, this time the NHS did indeed take centre stage in a number of the debates. This is because the NHS was flagged as one of the key issues of public concern. Ipsos MORI's political monitor of March 2015 found that " health care and the NHS" was the most important issue for voters in the run up to the election. Indeed, $38 \%$ stated it was a very important issue, up from $26 \%$ before the last general election. ${ }^{1}$ This is not just because of a commitment to the NHS but also because of the recognition of the pressures and strains on the public health service, which have been widely publicised in both the popular and the quality press. The main issues of debate in the run up to the election were funding, stealth privatisation of health services, quality of health services and governance issues.

\section{The NHS Funding Crisis}

According to the Institute of Fiscal Studies, the NHS is facing its worst financial crisis in 50 years. The crisis of funding started to become an issue in the 1990s. Between 1948 and 1999, NHS expenditure in England increased by $3 \%$ on average in real terms. However, it was clear by the end of the 1990s that the NHS was facing a financial and organisational crisis. Many people were reported to be dying on waiting lists. The Wanless reports of 2001 and $2002^{2}$ showed that successive governments had underinvested in the NHS by between $£ 220$ billion and $£ 267$ billion in the quarter century up to 1998 , which had led to lower achievements compared to continental Europe in terms of health performance. The reports called for an increase in spending to meet the needs of the population in terms of health. Thus, New Labour increased real spending between 6 and 7 per cent a year during much of the 2000s. From 2001-2002 to 2004-2005, spending on the NHS reached its highest level, increasing by $8.7 \%$ in real terms. The coalition government also increased spending during their time in government. However, in real terms this was in fact the lowest rate of growth in health spending recorded since 1955 , that is $0.6 \%{ }^{3}$

6 The Health Foundation reported that NHS spending per person was calculated as virtually flat, only increasing by $0.13 \%$ a year on average for the period 2009-2010 to $2015-2016 .{ }^{4} \mathrm{~A}$ number of recent reports have underlined the urgency to act to stop the NHS sinking. The interim and main report of the Commission on the Future of Health and Social Care ${ }^{5}$ concluded that a new settlement was necessary to face the huge pressures on the NHS 
and social care because of growing demands and constrained resources. It builds on the changes recommended in the Dilnot report, ${ }^{6}$ written by the Commission on Funding of Care and headed by Andrew Dilnot. This independent body was tasked by the government to review the funding system for care and support in England. This commission underlined the need for an additional $£ 3$ billion, rising to $£ 5$ billion by 2025 , to ensure that social care is provided free of cost. In the same vein as the Dilnot report, the interim report argued that England needs a single, ring-fenced budget for health and social care. The King's Trust also stated that additional funding of around $£ 2$ billion more than the current settlement is needed for next year. If this money is not found then staff cuts will have to be made and the level of care will most certainly decline. To fund the new NHS, the report suggests that charges should be applied to health care, cuts to other areas of public spending should be implemented and levels of taxation need to rise. These are reiterated in the final report. It points to the defects of the current fragmented system of funding and entitlement. Without any action taken, the burden will fall on the individual to provide his or her own care. They deem the current projections from the Office for Budget Responsibility to be too low. In addition to the Dilnot and the King's Fund reports, a survey carried out by the Association of Directors of Adult Social Services (ADASS), interviewing councils on NHS funding needs, concluded that the present system of social care is becoming "unsustainable". ${ }^{7}$ The Local Government Association (LGA) also estimated that councils would already be faced with a $£ 5.8$ billion shortfall by the end of the next financial year, including a $£ 1.9$ billion gap for adult social care ${ }^{8}$. Provider trusts have a deficit estimated at $£ 630$ million and many hospitals have reported deficits, showing a financial crisis across the system. However, perhaps one of the most influential reports in terms of funding needs in the run up to the 2015 elections was the NHS Five Year Forward View. ${ }^{9}$ In a follow up to the recommendations of this report, the NHS Chief Executive, Simon Stevens called for at least $£ 8$ billion in additional funds by 2020 and a further $£ 30$ billion in efficiency gains. The National Audit Office also recognized that current financial trends were unsustainable. ${ }^{10}$ Comparative studies of major economies of the EU show that there is a problem of underinvestment in the UK. In 2010, the UK spent 9.6\% of its national income on public and private health compared to $11.6 \%$ in France, $11.9 \%$ in Germany, Denmark, and the Netherlands and $11.2 \%$ in Austria and Canada. ${ }^{11}$

7 The future funding of the NHS therefore seems to be the main concern, which is essential to maintaining a high level of care and meet the demands of an ageing population. The British people seem to be on the whole against privatisation. Even proposals to charge for GP visits, as in other European countries, do not seem to be popular. Indeed, in England, there are only charges on prescriptions and dentistry, which raise about $£ 1.1$ billion. This is quite surprising because even Scandinavian countries, which are typically seen as highly collectivist, charge for GP visits. However, charges would also have to be applied to Accident and Emergency (A\&E) services to avoid diversion problems and this could cause a lot of administrative pressure and cost. The King's Fund concluded that it was not feasible to make changes to current NHS charges except for the treatment of accommodation or hotel costs outside hospital, and that new recipients of NHS healthcare could meet accommodation costs on a means-tested basis. Other solutions proposed are hypothecation, but earmarking taxes means that tax income can rise and fall and is therefore dependent on the economic cycle. Both Conservative and Labour chancellors have used tobacco tax to pay for NHS spending in the past. In 2002, Gordon Brown decided to add an additional 1 percentage point on National Insurance to pay for a large increase in NHS funding. However, there was no subsequent information on how it 
contributed to NHS funding. The King's Fund recommends the creation of a single, ringfenced budget for health and social care and a unique commissioner. They also argue that pensioners should pay a greater share of the burden. More affluent pensioners should not benefit from the winter fuel payments and free TV licenses. It also suggests revisions to wealth taxation and reforms to inheritance tax.

Many of the manifestos drew on such publicised reports to put forward proposals on how they would make up for the shortfall in funds, it being impossible to deny the need for this. Indeed, all parties agreed to the fact that the NHS should remain a tax-payer funded system, which is free at the point of use, based on a number of polls (such as the one shown in the figure below of March 2015) which showed that the British public was clearly in favour of keeping the NHS public.

\section{Do you think the following should be nationalised and run in the public sector, or privatised and run by private companies? $\%$}

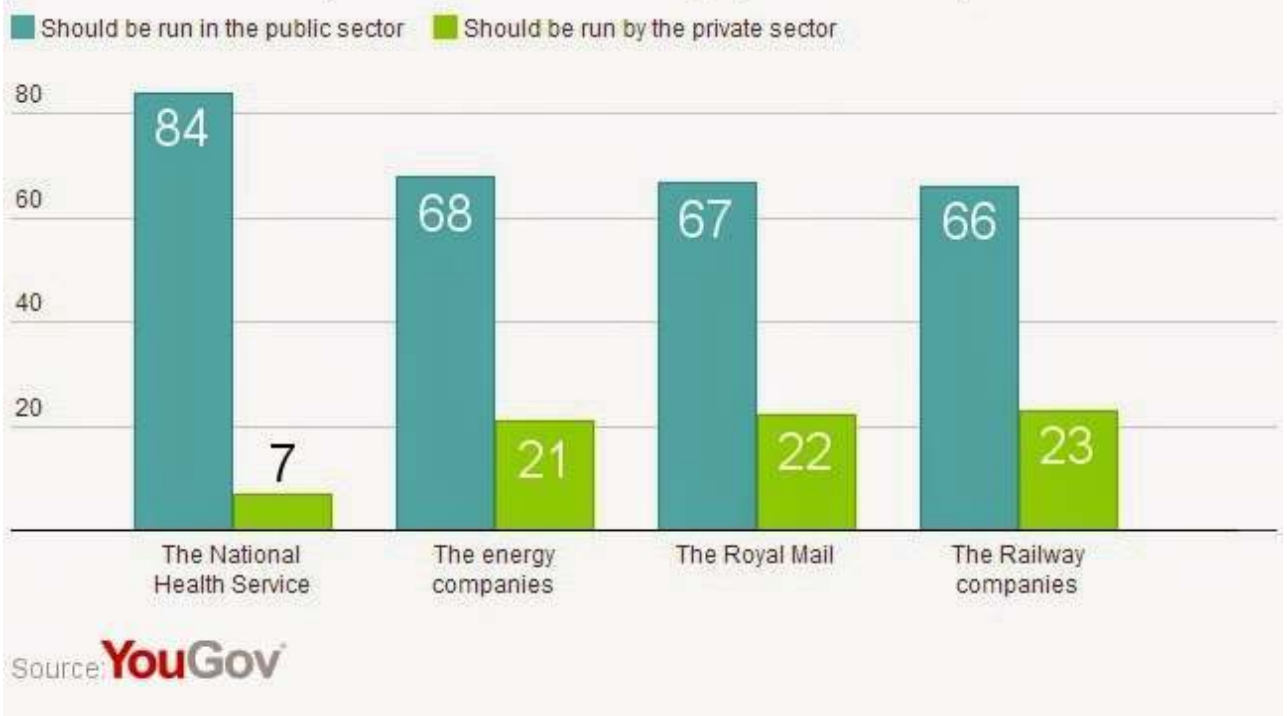

The Liberal Democrats were one of the first parties to pledge the extra $£ 8$ billion a year in NHS funding that was called for by Simon Stevens. However, they also claimed that this extra funding would not be made available until 2017-2018 when the deficit had been reduced and "the books balanced". While offering $£ 3$ billion a year more on the NHS, much of the focus of the UKIP party was on restricting NHS for migrants and visitors to the UK by requiring that they have medical insurance in order to access NHS services. Access to NHS services would only be made available if the "health visitor" had paid tax for 5 years in the UK. The Green Party pledged the highest amount in its manifesto: $£ 20$ billion a year in extra funding by 2020 . The Conservative party finally pledged to provide at least $£ 8$ billion by 2020 to support the NHS action plan over the next 5 years. Labour said it was committed to setting up a $£ 2.5$ billion-a-year "time to care" fund to pay for 20,000 more nurses, 8,000 more GPs and 3,000 more midwives. The Labour party tried to imply that services were under threat if the Conservatives were elected into office:

Our NHS, care services, schools, colleges and other public services make up the essential fabric of our society. People need them to be able to live secure and fulfilling lives. Britain needs them if we are to succeed as a country. But under the Conservatives they are under threat. The next Labour government will protect, improve and invest in our public services. ${ }^{12}$ 

Conservatives claimed to have cut administrative costs. Cameron announced that there are now 20,500 fewer managers, senior managers and administrative staff, and nearly 14,500 more professionally qualified clinicians than there were in 2010. But, Dr. Tomlinson $^{13}$ pointed out that cutting down on administrative staff does not necessarily result in a reduction in costs because medical professionals are doing a lot of the work such as choose and book ${ }^{14}$ coding, and so on, that could be classed as market costs. In April 2015, Andy Burnham, the Labour shadow health secretary, accused the Conservatives of allowing huge pay increases of $£ 35 \mathrm{~m}$ for NHS managers. He claimed that, if Labour was elected, it would make sure executive pay was not excessive: "It cannot be right at a time when NHS staff have been asked to accept years of freezes to see this level of excess at the top." ${ }^{15}$ According to the Department of Health, the average NHS trust chief executive in England earned $£ 163,679$ (average chief executive pay for all trusts) in 2014, which is higher than that of the British Prime Minister. ${ }^{16}$

\section{Providing Quality Health Services}

13 Another issue related to the lack of funding is the standard of health services. The performance of the NHS has been criticised because A\&E waiting times are the highest they have been for a decade and target waits for hospital treatment, diagnostic tests and cancer treatment are breached on a regular basis. Sir Merrick Cockell, former chairman of the LGA, criticised the fact that many old people were left in hospital beds because no residential care was available. ${ }^{17}$ However, it is difficult to measure whether overall quality of care in the NHS improved or not during the last Parliament. It is also too soon to assess the effects of reforms introduced in April 2013. However, most people are waiting longer to receive treatment than they were in 2010. Indeed, under the Coalition, hospitals have breached the waiting time target of under 4 hours in A\&E on a number of occasions. Nevertheless, $92 \%$ of patients were seen within this limit. Moreover, an international survey, carried out by the Commonwealth Fund, rated the UK first out of eleven countries in 2014. However, in some key areas the UK tends to fare less well than other countries. For example, infant mortality and deaths that could be prevented by effective health care are not highly ranked in the UK compared to other countries. It was estimated in 2010 that nearly a quarter of deaths under the age of 75 could have been prevented if appropriate health care had been provided, compared to $18 \%$ in France (which has the lowest amenable mortality rates in 19 key countries analysed). ${ }^{18}$

Focus has been on improving person-centred care since 2000 without consistent and effective indicators to measure whether this has been achieved. It has also been difficult

Revue Française de Civilisation Britannique, XX-3 | 2015 
to ensure appropriate funding has been directed for quality care. For example, mental illness accounts for $23 \%$ of total illnesses in the UK, but receives only $13 \%$ of NHS funding.

All parties seemed to take into account the need to bridge the gap between physical and mental care. The Liberal Democrats pledged to put an eighth of the extra $£ 8$ billion into providing care in people's homes and in communities to relieve pressure on hospital services. They maintained that they would guarantee equal care for mental health. Their manifesto also stated that the party would ensure improvements to waiting times for crisis care in A\&E, diagnostic tests and treatments. The Conservatives pledged to continue to ensure a high quality of health and social care. They promised same day GP appointments for the over $75 \mathrm{~s}$ and greater investment to fight against cancer and dementia. They accused Labour of covering up standards of care giving the example of Stafford and Morecambe Bay and poor cancer survival rates. They blamed the Labour government for nursing staff shortages that led to the Mid Staffordshire crisis. The Conservatives stated that they had increased access to drugs for cancer, increased dementia research and halved hospital infections. They drew on the Commonwealth Fund report to claim that, under the Conservatives, the NHS has become the best healthcare system of any major country. In the televised debate, Cameron claimed that waiting times had been reduced: "fewer patients waiting longer than the 18, 26 and 52 week targets than in May 2010". "We have slashed the number of people who wait over a year for the treatment they need, from over 18,000 to under $500 " .{ }^{19} \mathrm{He}$ claimed that the Conservatives would provide a truly 7 day NHS and that they were committed to implementing the NHS's Five Year Forward plan. The same commitment to mental health was also underlined. They promised to provide better health and social care for the terminally ill.

Labour accused the Conservatives of underinvesting and thus compromising the quality of care. It claimed that people have been waiting longer for tests and treatment. A 27page document, published by Douglas Alexander, Labour's election chief, reported that seven out of fifteen patients' rights set forth under the NHS constitution, had been breached under the coalition government. ${ }^{20}$ Labour pledged to invest in more staff which would be paid for out of a mansion tax on properties worth over $£ 2$ million, through a levy on tobacco firms and by cracking down on tax avoidance. It also stated its commitment to guaranteeing a GP appointment within 48 hours and an improvement in waiting times for cancer tests. Labour's manifesto promoted "joining-up" services around patients' needs.

17 All parties pledged to integrate care. However, they did not offer any solution to resolve the immediate pressures facing social care services. As the King's Trust Fund underlines: "Social care funding has become the ghost at the feast of this election campaign." 21

\section{Governing the new NHS}

The way the NHS is governed is also central to the debate on improving health services. Here we are referring to the shift from a central state to devolving accountability to governing agencies. Markets and other hierarchies can also be ways of governing. Governance in health is said to be "about the oversight and balancing of financial, clinical and patient satisfaction objectives." 22

19 Under the coalition government, a major shift has taken place under the Health and Social Care Act which came into force in 2013. Henceforth, GP practices must join Clinical Commissioning Groups (CCGs). These groups are responsible for commissioning services 
on behalf of patients in their practices. Previous to this Act, local health budgets were controlled by Primary Care Trusts where GPs could assess a patient's primary needs and refer him or her to a secondary service, for example a physiotherapist or a cardiologist, if necessary. The implications of replacing Primary Care Trusts with CCGs means that the GPs on CCGs are now responsible for commissioning budgets and have much more freedom to contract out services to the private sector. Previous governments, including New Labour, actually created and reinforced the internal market by introducing the purchaser/provider split. ${ }^{23}$ However, the significant change of replacing the Secretary of State's duty to make way for the GP commissioning process has entirely changed the notion of the NHS as a nationalised service and the essential governance of health services. GPs are now responsible for commissioning patient care but they may not be qualified for the job or there may be a conflict of interest because healthcare companies may encourage doctors to commission private treatment by offering them shares. CCGs function more like health insurance companies on the principle of membership and not automatic membership on an area basis. Homeless or new migrants may therefore not have equal access to health services.

It has also been pointed out that the Health and Social Care Act has made NHS governance more complex.

There's a sense in which nobody is in charge at a county level or a city-wide level when it comes to getting different organisations to work together both to implement the Five Year Forward View and to deal with the growing financial and service pressures within the NHS. ${ }^{24}$

In addition, there has been a move towards more localised decision-making under the coalition, which is welcomed by healthcare providers. For example Greater Manchester council's control will soon have a greater say over health spending. These changes will need to go hand-in-hand with improved methods of measuring outcomes. NHS Chief Historian, Professor Charles Webster ${ }^{25}$ argues that long A\&E waiting times, for example, should be the responsibility of all primary and community care providers, not just hospitals. He argues: "What we need is a simplified outcomes framework that aligns across healthcare, public health and social care." ${ }^{26}$ Governance therefore needs to bridge the gap between health and social care.

The Conservatives criticised Labour for its governance record and claimed to have improved the situation by cutting middle-management and PR. However, 3,400 press officers (PR or spin doctors) are still employed by local councils across the UK! The Conservatives also claimed that they had cleared out bureaucracy and made savings. Rather than setting managerial targets they have focused on outcomes and performance. They accused Labour of micro-managing from Whitehall and clogging up the system. However, the Conservatives have also been highly criticised for governing the NHS as a private entity.

\section{Towards the stealth privatisation of health services?}

The "privatisation" of the NHS, or more accurately the marketization of the NHS is a key point of dispute between political parties. Beyond the debate about the public good aspect of public services, is the question of quality. The criticism is that market forces drive down quality because private companies aim to win tenders and contracts by spending as 
little as possible on services and wish to maximise profits above all. Tendering out to the private sector has also resulted in increased pressure on hospital staff to meet targets.

One of the main providers of health services is Virgin Care, which has contracts worth hundreds of millions of pounds, running more than 230 NHS and social care services. Other private companies that have shown an active interest to take on NHS services are:Bio Product Laboratories (BPL), Care UK, Circle, General Healthcare Group (GHG), HCA International (Hospital Corporation of America), Ramsay, Spire Healthcare, The Practice PLC and UnitedHealth (Optum). The concern is that seven of the firms, including Virgin and GHS, have US subsidiaries which would enable them to use the EU-US Transatlantic Trade and Investment Partnership (T-TIP) to prevent the government blocking future bids or terminating existing contracts. The fear is that because many of these companies have strong US investment links, it would prevent the government from taking NHS contracts back into the public sector, unless it is clearly indicated in the T-TIP that the NHS is excluded.

Moreover, the expense of creating an artificial marketplace has also been underlined. Successive governments since the late 1980s (both left and right) have gradually put in place a system which allows private providers to compete with each other to offer services to the NHS. Dr Jacky Davis and other doctors and campaigners, including the National Health Action Party, estimated the cost at $£ 10$ billion per year. In 2010 the Health Select Committee reported that the cost of running the NHS as a market took up $14 \%$ of the NHS budget each year. The same committee pointed out that in the period before the market was introduced in the NHS, in the late 1980s, administration only accounted for $5 \%$ of the NHS budget. Even though the administration costs might have risen anyway as a proportion of the budget, it would seem that the market does tend to have more transaction costs - advertising, negotiating contracting, invoicing, billing, auditing, monitoring contracts, collecting information, resolving disputes both in court and out... For example, the legal fees that local Clinical Commissioning Groups had to pay to comply with one of the clauses of the Health and Social Care Act cost $£ 77$ million a year. NHS providers have also been criticised for the pay of their Chief Executives and hiring expensive management consultants. The Clinical Commissioning Groups are advised by costly commissioning support units, which were created under the coalition government and NHS England. Regulation to ensure the fair play of the market sector also costs money: NHS Trust Development Authority Monitor, the Care Quality Commission... Some of these bodies will be privatised soon. Removing these costs could free up funds to make up for the NHS shortfall and provide critical social care if market activities were reduced. A comparison with Scotland's hospital administration costs shows that in a less marketized system, there are fewer transaction costs. In the US, a country where the health sector is one of the most marketed in the world, much more money is spent on administering the system for poorer outcomes than the UK. Since the 1960s, there has been plenty of evidence to suggest that markets in health care just do not work. As Nobel Laureate Kenneth Arrow stated in $1963,{ }^{27}$ patients are not customers in a supermarket. It takes expertise that the common patient simply does not have and therefore choice should not be an issue. A marketed system also tends to provide incentives to over-treat, over-investigate and stimulate patient demand through advertising.

There is also evidence that marketization in the NHS has compromised care. In the Francis report that examined the failures of care at Mid Staffordshire, it was found that 
too much emphasis had been put on the market in running the hospital in order to get Foundation Trust status, which ended up compromising co-operation between medical professionals. Hinchinbrooke hospital, which is more or less run through the private sector, has been criticised by the Royal College of Nursing and the Care Quality Commission for poor standards of care and demoralised staff.

The Health and Social Care Act which came into force on 1 April 2013 has been accused of speeding up privatisation. The conditions of this act allows trusts to earn up to 49 per cent of their total income from private services. In addition, it gives groups of GP practices and professionals - Clinical Commissioning Groups (CCGs) - "real" budgets to buy care on behalf of their local communities; it transferred many of the responsibilities of the Department of Health to a new politically independent NHS Commissioning Board (this has now been renamed NHS England); it created a health specific economic regulator (Monitor) with a mandate to guard against "anti-competitive" practices; and moved all NHS trusts to foundation trust status. This has encouraged more tendering to the private sector because Clinical Commissioning Groups - also known as GP consortia -control about $£ 60$ billion of the NHS budget and are responsible for commissioning local services. Therefore, extra focus is actually put on commissioning. Commissioning takes place through competitive tendering and NHS contracts are therefore open for tender to the voluntary and private sectors. This has led to $£ 250$ million worth of NHS services being put out to tender, with 105 private firms granted contracts. This year, a further $£ 750$ million of services will be tendered. The conservatives claim that privatisation has not increased. However, according to the NHS trusts and financial regulator Monitor, average income from private patients per NHS foundation trust increased from £1.7 million (2009/10) to £2.7 million (2013/14), which represents an increase of 58\% ${ }^{28}$ Department for Health figures show that there has indeed been an increase in services commissioned from private providers since the Health and Social Care Act was implemented.

\section{Private providers in the NHS}

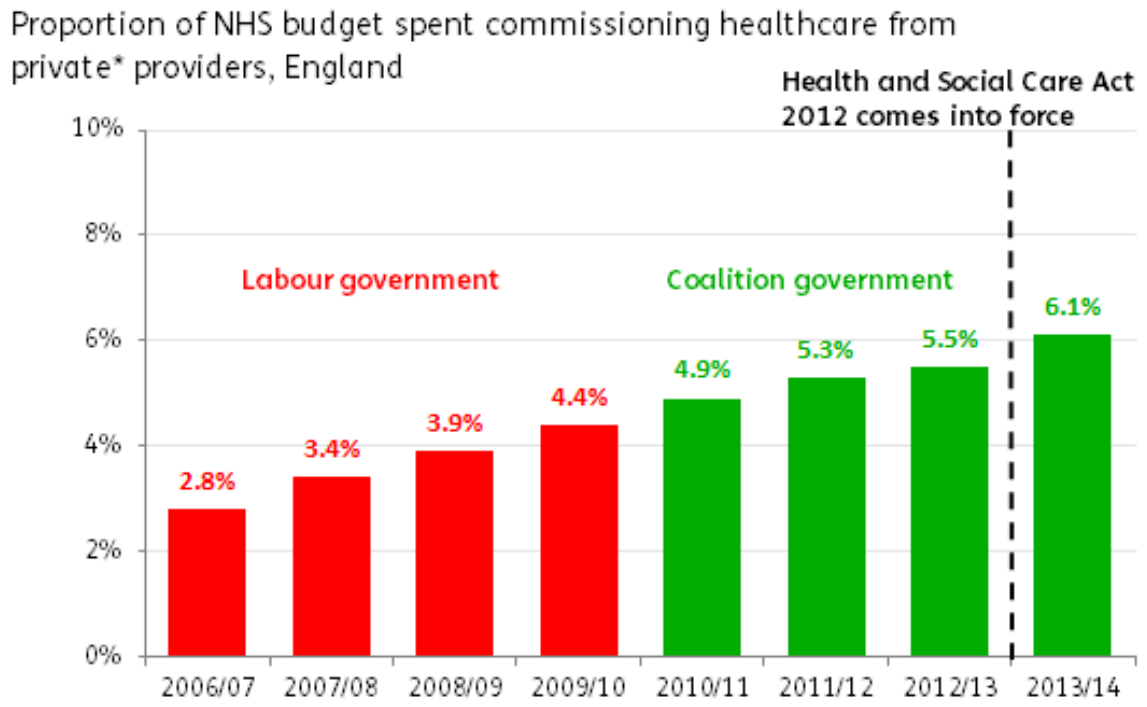

* Excludes local government, charities and the voluntary sector. 

criticised by both the popular and the quality press. Services outsourced to private companies through the PFI led to the compulsory redundancies of 4,620 frontline NHS staff between 2010/11 and 2012/13, and 2,430 voluntary redundancies. Since 2010, more than 30 NHS maternity and $42 \mathrm{A \& E}$ units have either been closed down or downgraded. ${ }^{29}$ Until 1990, hospitals did not have to pay a charge for their land, building and assets, but PFI hospitals must pay more than $15 \%$ of annual operating costs. Since the launching of the PFI in 1992, there has been an association with trust mergers which has led to a $30 \%$ reduction of hospital beds, staff lay-offs and closures of hospitals and community services. ${ }^{30}$ The hospitals are closed down because the government does not allow PFI hospitals to default on debt to avoid threatening other PFI schemes.

lly, marketization has also led to a target-driven approach. This tends to put extra pressure on staff and hospitals. For example, fines are imposed on A\&E departments that miss waiting time targets or receive too many patients. However, imposing fines is counterproductive and unfair since A\&Es are dealing with backlogs in care elsewhere.

The Liberal Democrats' manifesto claimed that it would moderate the marketization of the health system by securing local agreements on fully-pooled health and social care budgets and transfer responsibility for social care to the Department of Health, removing NHS mergers from the hands of the Competition and Markets Authority. Their manifesto said the party was committed to repealing any parts of the Health and Social Care Act which had made NHS services vulnerable to forced privatisation and affecting international agreements on free markets in goods and services. It stated that it would protect the NHS from being open to tender under the T-TIP. Nick Clegg claimed that he had had a guarantee from the EU that member states' rights to provide public services directly and not open to competition have been enshrined in the T-TIP.

In the televised debates, the Green Party heavily criticised the current government for the "creeping privatisation" of the NHS and called for the suppression of competition and the commissioner-provider split. In addition, the National Health Party (a party which was launched in 2012 by doctors, nurses, paramedics, NHS staff and ordinary members of the public to protest again the coalition's health reforms) said it would repeal the Health and Social Care Act to end competition in the NHS! It would introduce an NHS Bill to repeal the Health and Social Care Act and to end privatisation. "We will put an end to the billions of pounds of money wasted paying high interest rates on PFI debts originally brought in by the Tories and accelerated under New Labour." ${ }^{31}$ Although this party did not gain a seat, they got over 20,000 votes (more than the BNP and Monster Raving Loony Party) and will most likely put increasing pressure on the government to moderate tendering out to the private sector.

The Labour party stated that it would repeal the Health and Social Care Act of 2012. They claimed that they would scrap the competition regime and restore democratic accountability in the NHS and stop the drive towards privatisation. It also promised to make sure that services are not destabilised by competition and fragmentation. Labour does not actually intend to scrap commissioning to private companies but it said it would impose a cap on any profits made from the NHS to ensure that the needs of patients are always put first. It claimed that private health companies made a record $£ 18$ million each day from the NHS budget because more and more health contracts have gone to the private sector. Figures from the Department of Health underlined that last year $£ 6.6 \mathrm{bn}$ was taken from the NHS coffers to pay private health providers - a $50 \%$ rise from before

Revue Française de Civilisation Britannique, XX-3 | 2015 
the coalition took power. "The money we pay for healthcare must go on healthcare and not for excess profit for private firms," Ed Miliband said, and "Privatisation cannot meet the needs of a 21st Century health service." 32 The Labour manifesto stated that all outsourced NHS contracts valued at more than $£ 500,000$ would have to include a profit cap, with the default level set at $5 \%$. During the campaign trail in Stevenage, Miliband was also reported to have threatened: "A Tory second term means stealth privatisation of the National Health Service". Labour also promised that it would hold the European Commission to account on issues relating to public services and the Investor to State Dispute Settlement Mechanism ${ }^{33}$ regarding the T-TIP. Labour proposed to put a two per cent cap on work for private patients as a proportion of total income. Yet, they also stated that if the trust were to meet strict safeguards to ensure NHS patients are unaffected, then hospitals could exceed the two per cent limit. This led a Conservative spokesperson to dispute Labour's claim of scaling back privatisation and also added that, under the Conservatives, official figures show that outsourcing accounts for only $6 \%$ of NHS spending and that private patient income has actually fallen as a share of hospital budgets. However, as the King's Fund underlined,$^{34}$ Labour's manifesto marked a break with the past by rejecting markets and competition. The only concern was how Labour might dismantle the Health and Social Care Act without causing disruptive structural changes to the NHS. The manifesto was also criticised for proposing another top-down reorganisation. Labour thus pledged that local areas would be free to find their own routes to integration.

The Conservative manifesto is the only one that showed its intention to continue with the relentless move towards privatisation to encourage "the entrepreneurial spirit of public servants" and give all public sector organisations the right to mutualise. This could increase the trend introduced by the Health and Social Care Act of contracting out to Community Interest Companies (that is private firms that have a declared community benefit). Indeed, whereas in May 2010 fewer than 300 NHS staff worked for Community Interest Companies, 14,000 NHS staff now work for 17 Community Interest Companies.

\section{Conclusion}

The provision of health services and the future of the NHS were clearly priorities for most parties during the 2015 election. Key reports by the NHS, health organisations and the national press have brought to light the funding crisis that the National Health Service is currently facing in England. What is quite surprising about the 2015 election is that all parties seemed to agree on what is needed to sustain and improve health services in the UK: greater funding, greater support for mental health and dementia, reduced waiting lists and more integration of health and social care. Differences emerged in the figures, that is the additional money needed to "save" the NHS and the number of health professionals. There was also discord on the question of tendering out health services to the private sector. Whereas the Conservative party is quite happy to tender NHS services out to private companies, the Labour party and the Liberal Democrats want to cut back on this practice. The Green party called for an end to tendering out altogether.

The victory of the Conservative Party in the 2015 election means that it is unlikely that there will be yet more structural reforms to the NHS. The Conservatives have pledged to increase funding to meet the shortfall. However, most health organisations have pointed out that this is a bare minimum and unlikely to meet the needs of the NHS. Moreover, as the King's Fund evaluation of the manifesto pointed out ${ }^{35}$, the Conservatives do not say 
how they will fund the $£ 8$ billion a year. The fear is that because they have announced cuts, this may mean cutting social care budgets to be able to increase spending on the NHS. In an interview with Andrew Marr, David Cameron did not answer the question about where the extra money was coming from and whether this would involve further cuts (to the police force, social benefits...) The Conservative manifesto failed to address the challenges of increasing social care needs. Although the arguments for seven day services have already been supported by health service leaders and politicians, there are a number of challenges that will need to be overcome to ensure that the staff can be made available. Moreover, the Conservative Party promise to provide seven days a week services would require additional resources over and above the proposed $£ 8$ billion. The next 5 years will thus be crucial for the future of the National Health Service in Britain, especially faced with protest from sectoral interest groups and parties which offer an alternative to the marketed form of health service provision.

\section{BIBLIOGRAPHY}

ADASS., "Social care services 'unsustainable'”, 2 July 2014, <www.adass.org.uk>.

ALEXANDER, DOUGLAS. "NHS can't survive 5 more years of DC", Working Document, 5 January 2015, <www.nursingtimes.net/Journals/2015/01/05/c/k/x/150102---NHS-cant-survive-5-moreyrs-of-DC.pdf>, (accessed on 25 May 2015).

BBC., "Miliband warns of stealth privatization of NHS", 25 April 2015, <www.bbc.co.uk>.

COMMISSION ON FUNDING OF CARE AND SUPPORT FAIRER CARE FUNDING., "The Report of the Commission on Funding of Care and Support", 2011, http://

$<$ webarchive.nationalarchives.gov.uk>.

COMMISSION ON THE FUTURE OF HEALTH AND SOCIAL CARE., "A New Settlement for Health and Social Care", London: The King's Fund, 2014.

DEPARTMENT OF HEALTH., “The Senior Salaries Review Body”,. Department of Health, 2014.

DOUGLAS, Alexander, “NHS can't survive 5 more years of DC”, 5 January 2015, Working Document, 5 January 2015.

RIBGY, Elizabeth. “Labour focuses election campaign on NHS”, Financial Times, 4 January 2015.

HEALTH ORGANISATION., "NHS Finances - The challenge all political parties need to face", $<$ www.health.org.uk>.

JOUMARD I, ANDRE C and NIC C. , "Health care systems: efficiency and institutions", OECD Economics Department, Working Papers No. 769 OECD Publishing,: Paris, 20130, p.133.

LABOUR PRESS., "Ed Miliband's speech launching Labour's election campaign”, $<$ www.press.labour.org.uk>.

LOCAL GOVERNMENT ASSOCIATION., “Councils face £5.8 billion funding 'Black hole'”, $<$ www.local.gov.uk/finance>. 
LOCAL GOVERNMENT ASSOCIATION., "Adult social care funding: state of the nation report", Association of Directors of Adult Social Services, 2014.

NATIONAL AUDIT OFFICE., The financial sustainability of NHS bodies. HC 722 (2014-15),. Available at: $<$ www.nao.org.uk/wp-content/uploads/2014/11/The-financial-sustainability-of-NHS-

bodies.pdf>.

NHS ENGLAND., "Five year forward view", 2014, <www.england.nhs.uk/ourwork/futurenhs>.

STOREY, John et al., Governing the New NHS: Issues and Tensions in Health Service Management, New York: Routledge, 2010, p.2081.

THE HEALTH FOUNDATION., "Swimming against the tide? The quality of NHS services during the current Parliament", March $2015<$ www.health.org.uk>.

THE KING’s FUND., “General Election 2015: Analysis” <www.kingsfund.org.uk/topics/generalelection-2015>.

THOMAS, Kim., "What the healthcare sector wants from the next government", 10 March 2015, $<$ www.guardian.co.uk>,

WANLESS, Derek., Securing Our Future Health : Taking a Long-Term View, London: HMSO, 2002, p.164.

WANLESS, Derek., Securing Good Health for the Whole Population, London: HMSO, 2001, p. 51.

WINTOUR, P., “Ed Balls renews Labour’s commitment to NHS by promising extra $£ 2.5 \mathrm{bn}$ ”, 20 April 2015, <www.guardian.co.uk>.

\section{NOTES}

1. Reported in THE HEALTH FOUNDATION, "NHS finances - The challenges all parties need to face", Briefing, January 2015, <www.health.org.uk/fundingoverview> (accessed 25 April 2015).

2. Derek WANLESS, Securing Our Future Health: Taking a Long-Term View, London: HMSO, 2002; Derek WANLESS, Securing Good Health for the Whole Population, London: HMSO, 2001.

3. THE HEALTH FOUNDATION, "NHS finances - The challenges all parties need to face", Briefing, op.cit.

4. THE HEALTH FOUNDATION, "Swimming against the tide? The quality of NHS services during the current Parliament”, Briefing, March 2015, <www.health.org.uk/quality overview> (accessed 3 May 2015).

5. COMMISSION ON THE FUTURE OF HEALTH AND SOCIAL CARE, A New Settlement for Health and Social Care, London: The King's Fund, 2014.

6. COMMISSION ON FUNDING OF CARE AND SUPPORT FAIRER CARE FUNDING, The Report of the Commission on Funding of Care and Support, <http://webarchive.nationalarchives.gov.uk>, 2011 (accessed 26 May 2015).

7. ADASS, “Social care services 'unsustainable'", 2 July 2014, <www.adass.org.uk> (accessed on 3 May 2015).

8. LOCAL GOVERNMENT ASSOCIATION, "Councils face $£ 5.8$ billion funding 'Black hole", $<$ www.local.gov.uk/finance>, (accessed on 6 May 2015).

9. NHS ENGLAND, Five Year Forward View, 2014 <www.england.nhs.uk/ourwork/futurenhs>, (Accessed on 7 March 2015).

10. NATIONAL AUDIT OFFICE. The financial sustainability of NHS bodies. HC 722 (2014-15). Available at: <www.nao.org.uk/wp-content/uploads/2014/11/The-financial-sustainability-ofNHS-bodies.pdf.> (accessed on 7 May 2015). 
11. I. JOUMARD I, C. ANDRE and C. NIC, "Health care systems: efficiency and institutions", Economics Department Working Papers, No. 769, OECD: Paris, 2013.

12. The Labour Manifesto 2015, <http://www.labour.org.uk/manifesto>, (accessed on 12 May 2015).

13. Reported in Kim THOMAS, "What the Healthcare sector wants from the next government", 10 March 2015, <www.guardian.co.uk>, (accessed on 25 April 2015).

14. Choose and Book is a service that lets you choose your hospital or clinic and book your first appointment.

15. Patrick WINTOUR, “Ed Balls renews Labour's commitment to NHS by promising extra $£ 2.5$ bn”, 20 April 2015, <www.guardian.co.uk>, (accessed on 25 April 2015).

16. DEPARTMENT OF HEALTH, The Senior Salaries Review Body, Department of Health, 2014.

17. LGA "Adult social care funding: state of the nation report", Association of Directors of Adult Social Services, 2014.

18. THE HEALTH FOUNDATION, "Swimming against the tide? The quality of NHS services during the current Parliament", op. cit.

19. ITV, First Televised Election Debate.

20. DOUGLAS ALEXANDER, "NHS can't survive 5 more years of DC", Working Document, 5 January 2015, <www.nursingtimes.net/Journals/2015/01/05/c/k/x/150102---NHS-cant-survive-5-moreyrs-of-DC.pdf> (accessed on 25 May 2015).

21. THE KING'S FUND, “General Election 2015: Analysis" <www.kingsfund.org.uk/topics/generalelection-2015 (accessed on 16 April 2015).

22. John STOREY et al., Governing the New NHS: Issues and Tensions in Health Service Management, New York: Routledge, 2011.

23. Within internal markets in health care, the purchasing or commissioning of services on behalf of groups of the population (often geographically defined) is not carried out by the providers of services, which means tendering out services to the private or voluntary sectors.

24. Kim THOMAS, "What the Healthcare sector wants from the next government", op. cit.

25. Ibid

26. Ibid

27. Kim THOMAS, "What the Healthcare sector wants from the next government", op.cit.

28. HEALTH ORGANISATION, "NHS Finances - The challenge all political parties need to face", op.cit.

29. British Medical Association figures quoted in the Guardian: Denis CAMPBELL, " 7,000 key NHS clinical staff made redundant amid enforced cuts", The Guardian 21 December 2013, $<$ www.theguardian.com/society/2013/dec/31/nhs-staff-laid-offamid-savings-drive $>$ (accessed on 7 May 2015)

30. Ibid.

31. National Health Action Party, "NHA's key pillars for a healthy NHS and a healthy population" $<$ www.nhap.org $>$ (accessed on 7 May 2015).

32. LABOUR PRESS, “Ed Miliband's speech launching Labour's election campaign", $<$ www.press.labour.org.uk> (accessed on 6 May 2015).

33. The Investor-state dispute settlement (ISDS) is an instrument of public international law which grants an investor the right to use dispute settlement proceedings against a foreign government.

34. THE KING'S FUND, “General Election 2015: Analysis”, op. cit.

35. THE KING's FUND, “General Election 2015: Analysis” op.cit. 


\section{ABSTRACTS}

The 2015 general election in the UK saw the emergence of the health service and its future as one of the key points on the election battleground. This is because the NHS was flagged as one of the key issues of public concern. This is not just because of a commitment to the NHS but also the recognition of the pressures and strains on the public health service, widely publicised in both the popular and the quality press. The main issues of debate in the run up to the election were funding, stealth privatisation of health services, quality of health services and governance issues.

Les élections législatives de 2015 au Royaume-Uni ont vu l'émergence des services de santé et l'avenir du système de soins (National Health Service ou NHS) comme l'un des points clés d'affrontement de la campagne électorale. En effet, le NHS est l'un des principaux sujets de préoccupation publique, non seulement en raison de la popularité du système de santé publique, mais aussi en raison des menaces et incertitudes qui pèsent sur le système et qui ont été amplement médiatisées. Les principaux enjeux dans la course à l'élection furent le financement, la privatisation furtive des services de santé, la qualité des services de soins et les questions de gouvernance.

INDEX

Mots-clés: Elections législatives 2015, système national de santé, financement, privatisation, gouvernance

Keywords: UK General Election 2015, NHS, funding, privatisation, governance

\section{AUTHOR}

\section{LOUISE DALINGWATER}

Université Sorbonne Nouvelle - Paris 3 